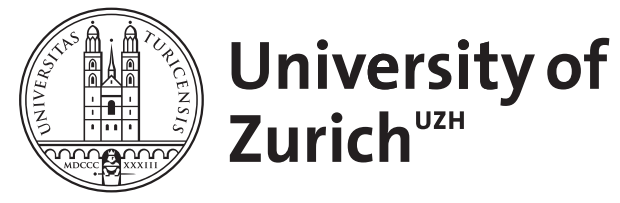

Zurich Open Repository and Archive

University of Zurich

University Library

Strickhofstrasse 39

CH-8057 Zurich

www.zora.uzh.ch

Year: 2011

\title{
Changing views of flower evolution and new questions
}

Endress, P K

DOI: https://doi.org/10.1017/CBO9781139013321.005

Posted at the Zurich Open Repository and Archive, University of Zurich

ZORA URL: https://doi.org/10.5167/uzh-57593

Book Section

Published Version

Originally published at:

Endress, P K (2011). Changing views of flower evolution and new questions. In: Wanntorp, L; Ronse de Craene, L. Flowers on the tree of life. Cambridge: University Press, 120-141.

DOI: https://doi.org/10.1017/CBO9781139013321.005 


\title{
Changing views of flower evolution and new questions
}

\author{
Peter K. Endress
}

\subsection{Flowers in phylogenetic and evolutionary studies}

The role of flowers in evolutionary biology has changed in the past 20 years, as the major foci are constantly changing with new approaches and better understanding of evolutionary processes. The revolution of molecular phylogenetics and molecular developmental genetics produced a trend in flower studies away from phylogenetics and towards evolution. In turn, the discovery of many well-preserved Cretaceous fossil flowers led to a new trend in flower studies towards phylogenetics, because fossil flowers do not provide DNA. The following three current fields of flower structural studies may be distinguished:

(1) Comparative morphological analysis offlowers - Many new major angiosperm clades have been recognized by molecular phylogenetic studies since Chase et al. (1993), as surveyed in APG $(1998,2009)$, Stevens (2001 onwards) and Soltis et al. (2005). These new clades need now to be critically studied comparatively in their structure and biology as they are largely unknown (e.g. Endress and Matthews, 2006; Endress, 2010a).

(2) Morphology for phylogenetic studies - Flowers were generally used for phylogenetic studies in the era before the molecular revolution. In the past 20 years,

Flowers on the Tree of Life, ed. Livia Wanntorp and Louis P. Ronse De Craene. Published by Cambridge University Press. () The Systematics Association 2011. 
phylogenetics has concentrated on molecular approaches, which yield more results in a shorter time than morphology. However, morphological phylogenetic analyses are still performed and yield interesting results, either alone or in combination with molecular analyses (at higher systematic levels, e.g. Nandi et al., 1998; Doyle and Endress, 2000, or lower levels, e.g. Carillo-Reyes et al., 2008; Sweeney, 2008). There has been a pessimistic attitude towards the use of morphological features in phylogenetics because of too much homoplasy (e.g. Givinish and Sytsma, 1997; Patterson and Givnish, 2002; Givnish, 2003; Scotland et al., 2003) and difficulties in scoring structural characters (Stevens, 2000). This is true if superficial structural features that are easy to spot are used (e.g. tepals large and showy versus small and inconspicuous, or fruits capsules versus berries, or storage organs rhizomes versus bulbs). However, morphology encompasses much more than such features. It can be expected that as our knowledge of flowers increases, there will be a resurgence in morphological phylogenetic analyses. In addition, the more fossil flowers become available, the more important morphological phylogenetic analyses will become (e.g. Friis et al., 2009; Doyle and Endress, 2010). There are not only many more fossil flowers available than 20 years ago, but there are also new techniques to reconstruct their morphology: the use of microtome section series (Schönenberger, 2005) and tomography (Friis et al., 2009). The search for and the detection of new structural patterns of interest is a continuing challenge. Characters and character states 'cannot be defined but need to be discussed,' as Wagner (2005) put it, meaning that definitions need to be constantly evaluated and updated to fit the current knowledge with each change in the phylogenetic framework. New knowledge on phylogeny (and evolution) continuously creates a new basis for discussion. Of course, if morphological characters are used for phylogenetic studies, this also means the necessity of repeated reciprocal illumination (see also Kelly and Stevenson, 2005). 'Tree-thinking' has been encouraged in evolutionary studies (O'Hara, 1988; Donoghue and Sanderson, 1992). This is of course also relevant for the focus on structural features, including the construction of morphological matrices for phylogenetic studies. The more detailed a tree under reconstruction already is and the more detailed our knowledge about the distribution of traits on this tree is, the better we can judge the quality of characters and character states to be scored.

(3) Morphology for evolutionary studies - The new phylogenetic results can now be used to study the evolution of flowers on a much more solid basis than was possible before. A general result is that many features are more evolutionarily flexible than previously assumed. A number of examples are surveyed in this study. Rarely is a character more stable than previously assumed at macrosystematic level; such an exception are features of ovules (Endress, 2003, 2005a, 2010). However, such flexibility is not randomly distributed through 
the larger clades. Given features are more concentrated (but not universal) in a certain clade than in another one. Why is this so? Answers can be expected from better knowledge of the genetic systems that operate in the development of such features (e.g. Borowsky, 2008; Melzer et al., 2008). Thus, homoplasy in structure is pervasive, much more common than earlier imagined and is a fascinating aspect of flower evolution (e.g. Cantino, 1985; Endress, 1996). For more evolutionary aspects of flower morphology, see Endress (1994, 2003, 2005b, 2006).

\subsection{Homology}

The terms homology and homologous were used originally to express that two parts that superficially look very different are in fact more similar and are evolutionarily derived from the same ancestral structure. Later, overapplication of the term in trying to find homologies for every little part has led to an inflation of the term. The attempt to work with 'partial homologies' in trying to determine at which percentage two parts are homologous (Sattler, 1992) is especially not helpful in understanding the evolution of structures. That there are continuities in the evolution of organisms in many ways is trivial. However, organisms are also characterized by a stratified complexity, and evolution proceeds with more or less hierarchical modules and patterns (e.g. Simon, 1962; Endress, 2005b). These patterns are the big issues to tackle in evolutionary biology. Thus a sensible evolutionary question in the detailed comparison of two parts is not by what percentage they are homologous, but in which respects they are homologous. Thus, one would like to know which aspects (submodules or subpatterns) they share with each other over their common ancestor.

How to proceed in the study of homology? Earlier recipes to assess homologies by morphologists such as Remane (1956), Eckardt (1964) and Kaplan (1984) are too strict and too restricted from a current perspective. However, this was reasonable at the time they were proposed. We are now in a different position. Earlier biologists used homologies to find systematic relationships and to understand phylogeny. Today it goes the other way around. We use homologies to understand evolution (and not phylogeny/relationships). Work with homologies gives a guideline. Thus we may proceed in the following way:

Detailed study of the structure in question, if possible with living material from entire plants available

Study of the development of the structure

- Comparison of the structure with the corresponding structure in the closest relatives (which may be less difficult to interpret) 


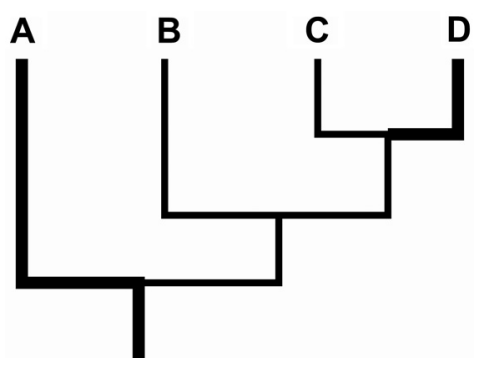

Fig 5.1 Re-appearance or re-institution in clade D of a feature (bold) present in clade A, which is missing in clades $\mathrm{B}$ and $\mathrm{C}$.

- Comparison with other groups with the same ecology (if an extreme ecology is connected with the special structure, for instance water plants) (e.g. Endress and Doyle, 2009).

In the era of cladistics, homology has sometimes been equated with synapomorphy. This is, however, only one side of the coin and thus of limited use in understanding the evolution of structures. A more differentiated view is proposed by Wagner $(1989,2007)$ who distinguishes between biological versus cladistic (phylogenetic) homology. Cladistic homology is used for synapomorphy, whereas biological homogy is used for morphological structures that have the same underlying genetic structure (see also Collin and Miglietta, 2008). The evolution of the genetic structure is an ever more fascinating field to tackle. A number of possible mechanisms for such evolutionary changes are currently being discussed, such as gene duplication and co-option of conserved modules (e.g. Causier et al., 2005; Irish and Litt, 2005; Rosin and Kramer, 2009) or frame-shifts (e.g. Lamb and Irish, 2003; Vargas and Wagner, 2009; Wagner, 2009).

In the example illustrated in Fig 5.1, the genetic machinery for the bold feature of clade $\mathrm{A}$ has not disappeared in clades $\mathrm{B}$ and $\mathrm{C}$, which do not exhibit the feature (the feature is repressed or not turned on), and is re-activated or re-instituted so that the feature reappears in clade D. Thus the bold feature shared by clades A and D is not homologous in a cladistic sense, but is homologous in a biological sense. Both aspects, cladistic homology (synapomorphy) and biological homology, are important in evolutionary biology.

\subsection{Alpha- and omega-morphology}

Morphology of plants has many different applications. Alpha-morphology (term coined here) is in morphology what alpha-taxonomy (Turrill, 1938) is in taxonomy. It is what many non-morphologists understand by morphology. It focuses on 
simple descriptions of plants as they are used for species descriptions, for floras or taxonomic revisions, mainly at the infrageneric level, or for the characterization of individuals in population biology. It deals with features that can rapidly and easily be seen, such as number and size of organs. It is one-dimensional, linear and measures simple parameters. In contrast, omega-morphology is an attempt to understand the structure of plants in evolutionary biology. It is multidimensional and includes all that can be attempted at a given time (comparative and molecular developmental morphology, floral biology, of extant and, if possible, fossil plants, evo-devo, evo-devo-eco) and it can always be improved by incorporating new aspects from various directions as they become available. A general goal of omega-morphology is an integrated understanding of form and function, and development and evolution. Morphological traits are shaped by history, likewise by organizational and ecological constraints, which both need to be considered to gain a deepened understanding of flower evolution (see also Endress, 2003; Givnish, 2003; Friedman et al., 2008).

Alpha-morphology can also be seen as a starting point for omega-morphology. Morphometrics (Klingenberg, 2009) and automated measurements of simple shapes and their variation (Lexer et al., 2009) are mostly used at the level of alpha-morphology. Omega-morphology is indispensable for evolutionary studies at higher levels, because changes in the organization of structures or structural complexes cannot commonly be represented by simple numbers and distances between reference points in structural units. Patterns of interest may be complex three-dimensional structures (especially the gynoecium) or complex branching systems of inflorescences with specific patterns of concatenation of branches, both of which may need developmental studies, or evaluation of a sequence of leaves with changing morphology on a shoot and patterns in this sequence, or patterns in the sequence of changing lateral branch differentiation along a gradient of subtending leaves in an inflorescence.

\begin{tabular}{lll}
\hline & Easy to assemble & $\begin{array}{l}\text { Interesting for (macro-) } \\
\text { phylogeny }\end{array}$ \\
\hline $\begin{array}{l}\text { Simple features, } \\
\text { Size, number: }\end{array}$ & + & -+ \\
(e.g. distance between two defined & & \\
points, number of specific organs) & & \\
Complex features, & & \\
Shape, pattern: \\
(e.g. position of parts in a system, \\
developmental sequence of specific \\
events)
\end{tabular}




\subsection{Detailed comparative morphological analysis for the elucidation of structural conundra}

An example of the different focuses in alpha- and omega-morphology are two publications on the family Oliniaceae (Myrtales). The study by Sebola and Balkwill (2009) deals with alpha-morphology, with the aim of an infrafamilial classification (low systematic level). This approach enabled a better understanding of the infrafamilial taxonomic differentiation. In contrast, the work by Schönenberger and Conti (2003) has a more omega-morphological approach, including developmental studies and comparison with the most closely related families Penaeaceae, Rhynchocalycaceae and Alzateaceae, and aims to understand the morphological and evolutionary relationships between Oliniaceae and related families. This approach enabled an understanding of the morphology of the puzzling perianth of Oliniaceae and, because the study included a phylogenetic analysis, an evaluation of its evolutionary relationships with the perianth of the other families.

Another example that goes beyond the level of alpha-morphology is the study of the morphological structure of cupules, which may be complex structures with a protective function for flowers and especially fruits. They are mainly known from several subclades of rosids. It has been shown by comparative developmental studies that, although they may look similar, not all cupules are homologous. In Fagales (Nothofagaceae, Fagaceae) and Sapindales (Anacardiaceae) they are complex, consisting of two or more sterile cymose branching systems, which are condensed, forming coenosomes (Fey and Endress, 1983; Rozefelds and Drinnan, 2002; Bachelier and Endress, 2007). In contrast, in Malpighiales (Balanopaceae), they are simple, consisting of a uniaxial rosette of bracts (Merino Sutter and Endress, 2003).

A third example is the morphological interpretation of reproductive units in Cyperaceae, in which a distinction between flowers and spikelets sometimes poses problems. A comparative developmental study in Exocarya (Cyperaceae) paved the way for a delimitation of flowers (Richards et al., 2006).

\subsection{Morphology of syncarpous gynoecia}

In flowers, syncarpous gynoecia are in general the most complex morphological structures. To describe syncarpous gynoecia there are two different classical approaches, that by Troll (1928) and that by Leinfellner (1950). Troll's approach has been used more often in morphological studies than Leinfellner's, because it is easier to apply. However, in view of developmental biology, Leinfellner's approach is more informative. Troll's approach with the distinction of (eu)syncarpous versus paracarpous focuses on the architecture in distinguishing septate versus 
non-septate ovaries. The weakness of this approach is that it does not consider that a septate ovary can arise by two different developmental processes: the septa can be congenitally uniform or they can arise by postgenital fusion. In contrast, Leinfellner focuses on this difference between congenital and postgenital organization. He recognizes that syncarpous gynoecia have two zones: at the base a zone in which there is congenital intracarpellary fusion, and above a zone with postgenital or no intracarpellary fusion. Thus, for Leinfellner it is not primarily important whether or not the ovary is septate, but whether intracarpellary fusion is congenital or postgenital. His focus is primarily on organization, and not architecture. It includes the reconstruction of the entire primary morphological surface, i.e. the surface that is derived from the floral apex. Thus the information content is greater than in Troll's approach. Concomitantly, Leinfellner's approach requires a more detailed morphological analysis with transverse microtome section series, and sometimes also study of younger developmental stages.

In general, if we don't know what happens with the primary morphological surface, we don't know a crucial aspect of development. Unfortunately, in many publications on gynoecium and other floral structures this aspect is not studied.

It is also useful to distinguish between morphology, anatomy and histology. Morphology is related to the development of the primary morphological surface. Histology deals with all the kinds of tissues in the organs. Anatomy is related to the patterns of distribution of the tissues in the organs and organ complexes, especially the architecture of the vasculature. For the analysis of all three levels, histology, anatomy and morphology, anatomical techniques are necessary.

In the studies on rosids in my lab, Merran Matthews and Julien Bachelier made detailed analyses of the gynoecium structure in larger clades and showed that all these aspects just mentioned, the topography of the inner morphological surface, anatomy and histology, are of systematic interest (Matthews et al., 2001; Matthews and Endress, 2002, 2004, 2005a, b, 2006, 2008; Bachelier and Endress, $2007,2008,2009)$. For related studies on other angiosperms, see, e.g. Remizowa et al. (2006).

\subsection{Concept of sepals and petals}

The concept of sepals and petals in angiosperms has been tackled from different perspectives, and new aspects have been discussed, but it is still not convincingly resolved how sepals and petals should be distinguished and where in the phylogenetic tree petals originated. It is an example of how difficult it is for the diversity perspective (Endress, 1994, 2005a, 2008a, 2010; Erbar et al., 1998; Ronse De Craene, 2007, 2008; Wanntorp and Ronse De Craene, 2009) and the model organism perspective to meet and be reconciled (Kramer and Irish, 1999; Davies et al., 2006; 
Litt, 2007; Irish, 2009; Rasmussen et al., 2009; Soltis et al., 2009; Warner et al., 2009; Kramer and Hodges, 2010; Yoo et al., 2010). A critical problem here is that for the shaping of organs of a given species, not only organ identity genes, but also genes for further differentiation are required. This 'fourth category' (following meristem identity genes, cadastral genes and organ identity genes) is not considered in the original ABC model of flower development by Coen and Meyerowitz (1991) and is commonly neglected in discussions. Within the framework of a single species (a 'model organism') this doesn't pop up as a problem, but if the entire diversity of angiosperms is considered, it does.

\subsection{Initiation of organs}

Unfortunately the terms initiation and primordium are often used in a sloppy and incorrect way in the literature, which may lead to misunderstandings of early developmental patterns. Organ initiation takes place within the floral apex and cannot be seen from the outside. An organ primordium is the very first developmental stage following initiation. It is at first not visible at the surface and then becomes visible as a shallow bump. An organ in a later stage is no longer a primordium. If primordial and slightly older stages are not distinguished, but lumped together, developmental patterns may be misinterpreted. The initiation of floral organs in the floral apex commonly proceeds in the centripetal (acropetal) direction. However, in multiparted, especially polystemonous, flowers, there is centrifugal (basipetal) direction in some clades (e.g. Leins, 1964; Endress, 1997; Rudall, 2010). Caution is especially needed because in some clades with completely centripetal stamen initiation patterns, the pattern of later development (maturation) becomes reversed, and is thus centrifugal. This is the case in some Winteraceae (Tucker, 1959; Doust, 2001; Doust and Drinnan, 2004) and some Ranunculaceae (Anemoneae, Aquilegia, and probably Glaucidium) (Tepfer, 1953; Ren et al., 2010). A functional aspect of centrifugal stamen initiation is that in polystemonous androecia the development of stamens becomes decoupled from that of the gynoecium, and in extreme cases the last initiated (outermost) stamens may have a different shape from the older ones. This pattern is used for heteranthery, which evolved especially in various pollen flowers (Endress, 2006). The significance in pollination biology of centrifugal stamen maturation has, to my knowledge, not been explored.

A more subtle problem is whether in highly integrated flowers with stable organ number and syncarpous gynoecium the gynoecium is initiated slightly before the stamens, or at least whether the prospective gynoecium area is determined earlier than the individual stamens, as suggested by molecular developmental genetic studies in Antirrhinum majus (Zachgo et al., 2000; Z. Schwarz-Sommer, pers. comm.) and by comparative structural studies in Arabidopsis thaliana (Choob and Penin, 2004). In 
Duparquetia (Leguminosae) the single carpel appears before the stamens (Prenner and Klitgaard, 2008). In polystemonous flowers, such as in Dillenia (Dilleniaceae) or Couroupita (Lecythidaceae) the carpels appear earlier than the individual stamens, which are formed on primary ring primordia (e.g. Endress, 1994, 1997).

\subsection{Current perception of evolutionary patterns}

The course and direction of evolution is more flexible than previously thought. This is brought clearly to light by the ever more detailed phylogenetic studies on flowering plants and elsewhere. Previously, for example, evolution of a superior ovary from an inferior one was thought to be so unusual that an obvious example was published in Science (Tetraplasandra, Eyde and Tseng, 1969). One of the most cited features of flexible evolution is the multiple and complex evolution of C4 photosynthesis (e.g. Besnard et al., 2009). There are also many examples from flowers, which are shown here. Thus we have to be much more differentiated as to what we call apomorphies or synapomorphies.

\subsubsection{Inferior $\longleftrightarrow$ superior ovary}

The above-mentioned example of Tetraplasandra species with secondarily superior ovaries in Araliaceae has been further corroborated. It has also been shown, however, that development begins as for an inferior ovary (Costello and Motley, $2001,2004,2007)$. Thus the superior state is both developmentally and evolutionarily secondary. In addition, species with a 'superior' ovary in Tetraplasandra form a single clade (Costello and Motley, 2007). Another genus in Araliaceae with a secondarily superior ovary is Dipanax (Wen et al., 2001). Also in Rubiaceae several genera were found to have secondarily superior ovaries (Gaertnera, Igersheim et al., 1994; Mitrasacmopsis, Groeninckx et al., 2007; overview, Igersheim et al., 1994; Endress, 2002). Families in rosids with secondarily superior ovaries are Vochysiaceae (Litt and Stevenson, 2003a, b), and Saxifragales are especially flexible in the transitions between superior and inferior ovaries at various systematic levels (e.g. level of family Saxifragaceae, level of genus Lithophragma, Hufford and McMahon, 2003; Soltis et al., 2005). Examples of families in monocots containing clades with secondarily superior ovaries include Hemerocallidaceae and Xanthorrhoeaceae (Rudall, 2002), Haemodoraceae (Simpson, 1998) and Bromeliaceae (Sajo et al., 2004).

\subsubsection{Decrease $\longleftrightarrow$ increase in floral organ number}

Earlier, evolution was mainly seen in terms of reduction from many to a few parts. We now know that this is not the case at many levels. In basal angiosperms evolution in number of all floral parts, including ovules, is flexible (Doyle and Endress, 
2000, this volume; Endress and Doyle, 2009). In Rubiaceae (Psychotrieae alliance) ovule number per carpel is increased from one to many (Razafimandimbison et al., 2008).

\subsubsection{Whorled $\longleftarrow$ spiral floral phyllotaxis}

Contrary to earlier beliefs, floral phyllotaxis patterns are very flexible. The direction is not only from spiral to whorled, but there was repeated evolution of spiral phyllotaxis from whorled in the perianth in basal angiosperms (Endress and Doyle, 2007, 2009; Doyle and Endress, 2011) and there is much evolutionary flexibility of patterns within families, genera or even species (Endress, 1987; Staedler and Endress, 2009).

\subsubsection{Repeated evolution of a double perianth}

That a double perianth was reduced during evolution in many groups of eudicots has long been known. However, in some clades there was also repeated evolution of a double perianth with sepals and petals from a simple perianth with only one kind of organ or a fluctuation between both traits. An example is Caryophyllales sensu lato (APG, 2009), which originally had a simple perianth and a double perianth evolved independently in several families (Brockington et al., 2009), with petals at least in part derived from the androecium (Ronse De Craene, 2008).

\subsubsection{Floral monosymmetry $\longleftrightarrow$ floral polysymmetry}

There are evolutionary trends from polysymmetric to monosymmetric flowers in various angiosperm groups. However, the opposite direction can also be found (Endress, 1999). The best-known pathway is polysymmetry by pelorization of monosymmetric flowers (e.g. Cadia, Leguminosae, Citerne et al., 2006). A more complex case is the trend from pronounced monosymmetric to more or less polysymmetric flowers in some Lecythidaceae-Lecythidoideae (Allantoma/Cariniana decandra) (Tsou and Mori, 2007).

\subsubsection{Repeated evolution of floral asymmetry from monosymmetry at several levels within a larger clade}

In Fabales both large families, Fabaceae and Polygalaceae, have groups with conspicuously asymmetric flowers (e.g. Prenner, 2004). At the level of the family Fabaceae, asymmetric flowers evolved in several subclades, especially in Cassiinae of caesalpinioids, and in Phaseoleae and Vicieae of papilionoids. At the level of the subtribe Cassiinae, species of Chamaecrista and Senna have asymmetric flowers. At genus level, in Senna floral asymmetry evolved independently in several subclades (Marazzi et al., 2006; Marazzi and Endress, 2008). For distribution of asymmetry in angiosperms, see Endress (accepted). 


\subsubsection{Complex flowers $\longleftarrow$ simple flowers}

The evolution of complex flowers is based on repeated synorganization of structural units (e.g. Endress, 2006). However, complexity may also be lost in evolution, as shown in Amorpheae (Leguminosae), in which the architecture of complex keel flowers has been lost (McMahon and Hufford, 2005), or in Besseya (Plantaginaceae), in which the corolla tube disappeared (Hufford, 1995).

\subsubsection{Shortening and secondary elongation of sepals with lost primary function}

In Thunbergioideae (Acanthaceae), flower evolution went through a conspicuous transference of function. The two floral prophylls became the protective organs up to anthesis, whereas the sepals that previously had this function became reduced (Schönenberger and Endress, 1998; Schönenberger, 1999). This reduction is expressed in shortening and narrowing, and sometimes complete loss of the sepals. Concomitant with this reduction, if the sepals are not completely lost, is an increase in number of the small sepals. In some moth-pollinated species with extremely elongate corolla, the reduced sepals are secondarily elongated as well, however, without re-gaining the lost protective function, and this secondary elongation seems to be merely a passive by-product of the elongation of the corolla (Endress, 2008b). Phylogenetic analysis shows that such secondary elongation evolved more than once (Borg et al., 2008).

\subsubsection{Inflation of calyx}

In some Solanaceae, the synsepalous calyx becomes inflated and balloon-like during fruit development. This 'inflated-calyx syndrome' evolved several times (or became lost several times) within the family (Hu and Saedler, 2007).

\subsubsection{Centripetal versus centrifugal stamen initiation in polystemonous androecia}

The subclass Dilleniidae was introduced into angiosperm macrosystematics by Takhtajan (1964) largely influenced by the occurrence of centrifugal stamen initiation in polymerous androecia, which was supposed to be a fundamentally important pattern in macrosystematics. However, the subclass was later dismantled, first by structural cladistic studies (Hufford, 1992) and then also by molecular studies (Chase et al., 1993) (see also Endress et al., 2000). From the present perspective, the feature is not stable at very high systematic levels, however, often it is still at family level.

\subsubsection{Rapid evolution and diversification of floral traits}

In some groups with a relatively recent diversification, evolutionary changes in floral size or floral structure are unusually massive. The most striking example is perhaps Rafflesia, which surprisingly is related to Euphorbiaceae (Davis et al., 2007), a generally small-flowered group, but which has flowers that reach almost one metre in diameter in some species; this gigantism evolved relatively recently, in less than 
50 my (Barkman et al., 2008; Davis, 2008). Another example is the genus Impatiens, which became very diverse, with currently more than 1000 species, in a short time (mostly in less than 5 my) (Janssens et al., 2009). In what ways inner conditions enabled these rapid changes is unknown.

\subsubsection{Flexibility of pollination system transitions}

Flexibility of pollination system transitions has been studied in numerous groups of angiosperms. Some conspicuous examples are be mentioned here. Among Phyllanthaceae, 'in Phyllantheae, specialization to pollination by Epicephala moths evolved at least five times, involving more than 500 Phyllantheae species in this obligate association' (Kawakita and Kato, 2009).

Floral architecture in Mitella (including Tolmiea, Lithophragma, Heuchera, Bensoniella) (Saxifragaceae), many of which are pollinated by fungus gnats, fluctuates in evolution, including 'saucer-shaped' flowers, flowers with 'pollination organs projected', and flowers with 'pollination organs enclosed' (Okuyama et al., 2008).

Fluctuation between bee and hummingbird pollination has found special attention (Cronk and Ojeda, 2008). Case studies of such flexibility are those of Penstemon and Keckiella (Veronicaceae) (Wilson et al., 2007), Sinningieae (Gesneriaceae) (Perret et al., 2007) and Ruellia (Acanthaceae) (Tripp and Manos, 2008). Fluctuation between different pollination syndromes occurs in Iochrominae (Solanaceae) (Smith and Baum, 2006). For Pedicularis (Orobanchaceae) it has been shown which functional floral traits are more homoplastic than others and also that floral tube tube length is especially plastic (Ree, 2005). Renner and Schaefer (2010) calculated that oil flowers in angiosperms evolved at least 28 times and floral oil was lost at least 36-40 times.

\subsubsection{Stability of patterns}

However, there are a few features that now appear to be more stable than previously thought, especially in ovule structure, such as nucellus thickness and number of integuments. New studies have continuously reinforced this picture (Endress et al., 2000; Endress, 2003, 2010; Endress and Matthews, 2006). Additional ovule structural features have also recently been found to be of macrosystematic significance (relative thickness of inner and outer integument, Endress and Matthews, 2006).

\subsection{Summary and outlook}

The combination of ever more fine-grained phylogenetic analyses and mapping of morphological features in such cladograms has shown that evolutionary transitions of all kinds in floral structure are much easier than previously believed. There are almost no limitations for evolutionary directions in floral features. Nevertheless, certain directions are clearly favoured compared with others. Specific trends can be found in certain clades, i.e. the concentrated and often several times repeated appearance of a feature. This suggests 'biological homology' in the sense of Wagner 
$(1989,2007)$. It will be important to know in more detail in which clades and at what evolutionary level particular features are stable or labile. This will have repercussions on the coding of floral morphological characters for phylogenetic analyses.

Comparative floral morphology needs to include a developmental component for the reconstruction of the primary morphological surface (which is enclosed in the gynoecium and potentially in other organ complexes and then does not form the topographical surface of the organ or organ complex). The primary morphological surface is sometimes no longer apparent at anthesis in cases in which postgenital fusion takes place.

Patterns in the sequence of origin of floral organs are often constant at lower or higher phylogenetic levels. Initiation takes place before the organ becomes visible at the surface. There are errors in the literature with regard to centripetal and centrifugal initiation, because the term 'primordium' is sometimes used in a sloppy way, and initiation and post-initiation development are not correctly distinguished. But when is an organ initiated and when is it a 'primordium'? This needs more profound critical study.

New conceptional and methodical developments need to be constantly integrated into morphological research. A lot is to be expected from evo-devo research, from the study of the wealth of floral fossils available, and from the comparative study of newly found clades.

\section{Acknowledgements}

Louis Ronse De Craene and Livia Wanntorp are thanked for the invitation to participate in the symposium on 'Flowers on the Tree of Life', held in Leiden, Netherlands, in August 2009. I especially thank James A. Doyle, Merran L. Matthews, Julien B. Bachelier and Yannick M. Staedler for discussions. Zsuzsanna Schwarz-Sommer is thanked for information on floral development in Antirrhinum majus. Alex Bernhard is acknowledged for graphic work. I also thank the Swiss National Science Foundation. Although this publication is not directly part of a project supported by the Foundation, it greatly profited from two earlier projects that were (3100040327.94 and 3100-059149.99/1).

\subsection{References}

APG (1998). An ordinal classification for the families of flowering plants. Annals of the Missouri Botanical Garden, 85, 531-553.

APG (2009). An update of the Angiosperm Phylogeny Group classification for the orders and families of flowering plants: APG III. Botanical Journal of the Linnean Society, 161, 105-121.

Bachelier, J. B. and Endress, P. K. (2007).

Development of inflorescences, cupules, and flowers in 
Amphipterygium, and comparison with Pistacia (Anacardiaceae). International Journal of Plant Sciences, 168, 1237-1253.

Bachelier, J. B. and Endress, P. K. (2008). Floral structure of Kirkia (Kirkiaceae) and its position in Sapindales. Annals of Botany, 102, 539-550.

Bachelier, J. B. and Endress, P. K. (2009). Comparative floral morphology and anatomy of Anacardiaceae and Burseraceae (Sapindales), with a special focus on gynoecium structure and evolution. Botanical Journal of the Linnean Society, 159, 499-571.

Barkman, T. J., Bendiksby, M., Lim, S.-H. et al. (2008). Accelerated rates of floral evolution at the upper size limit for flowers. Current Biology, 18, 1508-1513.

Besnard, G., Muasya, A. M., Russier, F. et al. (2009). Phylogenomics of C4 photosynthesis in sedges (Cyperaceae): multiple appearances and genetic convergence. Molecular Biology and Evolution, 26, 1909-1919.

Borg, A. J., McDade, L. A. and Schönenberger, J. (2008). Molecular phylogenetics and morphological evolution of Thunbergioideae (Acanthaceae). Taxon, 57, 811-822.

Borowsky, R. (2008). Restoring sight in blind cavefish. Current Biology, 18, R23-R24.

Brockington, S. F., Alexandre, R., Ramdial, J. et al. (2009). Phylogeny of the Caryophyllales sensu lato: Revisiting hypotheses on pollination biology and perianth differentiation in the core Caryophyllales. International Journal of Plant Sciences, 170, 627-643.

Cantino, P. (1985). Phylogenetic inference from nonuniversal derived character states. Systematic Botany, 10, 119-122.
Carrillo-Reyes, P., Sosa, V. and Mort, M. E. (2008). Thompsonella and the 'Echeveria group' (Crassulaceae): Phylogenetic relationships based on molecular and morphological characters. Taxon, 57, 863-874.

Causier, B., Castillo, R., Zhou, J. L. et al. (2005). Evolution in action: Following function in duplicated floral homeotic genes. Current Biology, 15, 1508-1512.

Chase, M. W., Soltis, D. E., Olmstead, R. G. et al. (1993). Phylogenetics of seed plants: An analysis of nucleotide sequences from the plastid gene rbcL. Annals of the Missouri Botanical Garden, 80, 528-580.

Choob, V. V. and Penin, A. A. (2004). Structure of flower in Arabidopsis thaliana: Spatial pattern formation. Russian Journal of Developmental Biology, 35, 224-227.

Citerne, H. L., Pennington, R. T. and Cronk, Q. C. B. (2006). An apparent reversal in floral symmetry in the legume Cadia is a homeotic transformation. Proceedings of the National Academy of Sciences USA, 103, 12017-12020.

Coen, E. S. and Meyerowitz, E. M. (1991). The war of the whorls: Genetic interactions controlling flower development. Nature, 353, 31-37.

Collin, R. and Miglietta, M. P. (2008). Reversing opinions on Dollo's law. Trends in Ecology and Evolution, 23, 602-609.

Costello, A. and Motley, T. J. (2001). Molecular systematics of Tetraplasandra, Munroidendron and Reynoldsia sandwicensis (Araliaceae) and the evolution of superior ovaries in Tetraplasandra. Edinburgh Journal of Botany, 58, 229-242.

Costello, A. and Motley, T. J. (2004). The development of the superior ovaries in 
Tetraplasandra (Araliaceae). American Journal of Botany, 91, 644-655.

Costello, A. and Motley, T. J. (2007). Phylogenetics of the Tetraplasandra group (Araliaceae) inferred from ITS, 5S-NTS, and morphology. Systematic Botany, 32, 464-477.

Cronk, Q. and Ojeda, I. (2008). Birdpollinated flowers in an evolutionary and molecular context. Journal of Experimental Botany, 59, 715-727.

Davies, B., Cartolano, M. and SchwarzSommer, Z. (2006). Flower development: The Antirrhinum perspective. Advances in Botanical Research, 44, 279-319.

Davis, C. C. (2008). Floral evolution: Dramatic size change was recent and rapid in the world's largest flowers. Current Biology, 18, R1102-R1104.

Davis, C. C., Latvis, M., Nickrent, D. L., Wurdack, K. J. and Baum, D. A. (2007). Floral gigantism in Rafflesiaceae. Science, 315, 1812.

Donoghue, M. J. and Sanderson, M. J. (1992). The suitability of molecular and morphological evidence in reconstructing plant phylogeny. pp. 340-368 in Soltis, P. S., Soltis, D. E. and Doyle, J. J. (eds.), Molecular Systematics of Plants. New York: Chapman and Hall.

Doust, A. N. (2001). The developmental basis of floral variation in Drimys winteri (Winteraceae). International Journal of Plant Sciences, 162, 697-717.

Doust, A. N. and Drinnan, A. N. (2004). Floral development and molecular phylogeny support the generic status of Tasmannia (Winteraceae). American Journal of Botany, 91, 321-331.

Doyle, J. A. and Endress, P. K. (2000). Morphological phylogenetic analysis of basal angiosperms: Comparison and combination with molecular data. International Journal of Plant Sciences, 161, S121-S153.

Doyle, J. A. and Endress, P. K. (2010). Integrating Early Cretaceous fossils into the phylogeny of living angiosperms: Magnoliidae and eudicots. Journal of Systematics and Evolution, 48, 1-35.

Doyle, J. A. and Endress, P. K. (2011). Tracing the early evolutionary diversification of the angiosperm flower. pp. 85-117 in Wanntrop, L., Ronse De Craene, (eds.), Flowers on the Tree of Life. Cambridge: Cambridge University Press.

Eckardt, T. (1964). Das Homologieproblem und Fälle strittiger Homologien. Phytomorphology, 14, 79-92.

Endress, P. K. (1987). Floral phyllotaxis and floral evolution. Botanische Jahrbücher für Systematik, 108, 417-438.

Endress, P. K. (1994). Diversity and Evolutionary Biology of Tropical Flowers. Cambridge: Cambridge University Press.

Endress, P. K. (1996). Homoplasy in angiosperm flowers. pp. 301-323 in Sanderson, M. J. and Hufford, L. (eds.), Homoplasy and the Evolutionary Process. Orlando: Academic Press.

Endress, P. K. (1997). Relationships between floral organization, architecture, and pollination mode in Dillenia (Dilleniaceae). Plant Systematics and Evolution, 206, 99-118.

Endress, P. K. (1999). Symmetry in flowers diversity and evolution. International Journal of Plant Sciences, 160, S3-S23.

Endress, P. K. (2002). Morphology and angiosperm systematics in the molecular era. Botanical Review, 68, 545-570.

Endress, P. K. (2003). What should a 'complete' morphological phylogenetic analysis entail? Regnum Vegetabile, 141, 131-164. 
Endress, P. K. (2005a). Links between embryology and evolutionary floral morphology. Current Science, $\mathbf{8 9}$, 749-754.

Endress, P. K. (2005b). The role of morphology in angiosperm evolutionary studies. Nova Acta Leopoldina, 92 (342), 221-238.

Endress, P. K. (2006). Angiosperm floral evolution: Morphological and developmental framework. Advances in Botanical Research, 44, 1-61.

Endress, P. K. (2008a). Perianth biology in the basal grade of extant angiosperms. International Journal of Plant Sciences, 169, 844-862.

Endress, P. K. (2008b). The whole and the parts: relationships between floral architecture and floral organ shape, and their repercussions on the interpretation of fragmentary floral fossils. Annals of the Missouri Botanical Garden, 95, 101-120.

Endress, P. K. (2010). Floral structure and trends of evolution in eudicots and their major subclades. Annals of the Missouri Botanical Garden, 97, 541-583.

Endress, P. K. (accepted). The immense diversity of floral monosymmetry and asymmetry.

Endress, P. K. and Doyle, J. A. (2007). Floral phyllotaxis in basal angiosperms development and evolution. Current Opinion in Plant Biology, 10, 52-57.

Endress, P. K. and Doyle, J. A. (2009). Reconstructing the ancestral flower and its initial specializations. American Journal of Botany, 96, 22-66.

Endress, P. K. and Matthews, M. L. (2006). First steps towards a floral structural characterization of the major rosid subclades. Plant Systematics and Evolution, 260, 223-251.

Endress, P. K., Baas, P. and Gregory, M. (2000). Systematic morphology and anatomy: 50 years of progress. Taxon, 49, 401-434.

Erbar, C., Kusma, S. and Leins, P. (1998). Development and interpretation of nectary organs in Ranunculaceae. Flora, 194, 317-332.

Eyde, R. H. and Tseng, C. C. (1969). Flower of Tetraplasandra gymnocarpa. Hypogyny with epigynous ancestry. Science, 166, 506-508.

Fey, B. S. and Endress, P. K. (1983). Development and morphological interpretation of the cupule in Fagaceae. Flora, 173, 451-468.

Friedman, W. E., Barrett, S. C. H., Diggle, P. K., Irish, V. F. and Hufford, L. (2008). Whither plant evo-devo? New Phytologist, 178, 468-471.

Friis, E. M., Pedersen, K. R., von Balthazar, M., Grimm, G. W. and Crane, P. R. (2009). Monetianthus mirus gen. et sp. nov., a nymphaealean flower from the Early Cretaceous of Portugal. International Journal of Plant Sciences, 170, 1086-1101.

Givnish, T. J. (2003). How a better understanding of adaptations can yield better use of morphology in plant systematics: Toward eco-evo-devo. Regnum Vegetabile, 141, 273-295.

Givnish, T. J. and Sytsma, K. J. (1997). Homoplasy in molecular vs. morphological data: The likelihood of correct phylogenetic inference. pp. 55-101 in Givnish, T. J. and Sytsma, K. J. (eds.), Molecular Evolution and Adaptive Radiation. Cambridge: Cambridge University Press.

Groeninckx, I., Vrijdaghs, A., Huysmans, S., Smets, E. and Dessein, S. (2007). Floral ontogeny of the Afro-Madagascan genus Mitrasacmopsis with comments on the development of superior ovaries in Rubiaceae. Annals of Botany, 100, 41-49. 
Hu, J.-Y. and Saedler, H. (2007). Evolution of the inflated calyx syndrome in Solanaceae. Molecular Biology and Evolution, 24, 2443-2453.

Hufford, L. (1992). Rosidae and their relationships to other nonmagnoliid dicotyledons: A phylogenetic analysis using morphological and chemical data. Annals of the Missouri Botanical Garden, 79, 218-248.

Hufford, L. (1995). Patterns of ontogenetic evolution in perianth diversification of Besseya (Scrophulariaceae). American Journal of Botany, 82, 655-680.

Hufford, L. and McMahon, M. (2003). Beyond morphoclines and trends: The elements of diversity and the phylogenetic patterning of morphology. Regnum Vegetabile, 141, 165-186.

Igersheim, A., Puff, C., Leins, P. and Erbar, C. (1994). Gynoecial development of Gaertnera Lam. and of presumably allied taxa of the Psychotrieae (Rubiaceae): secondarily 'superior' vs. inferior ovaries. Botanische Jahrbücher für Systematik, 116, 401-414.

Irish, V. F. (2009). Evolution of petal identity. Journal of Experimental Botany, 60, 2517-2527.

Irish, V. F. and Litt, A. (2005). Flower development and evolution: Gene duplication, diversification and redeployment. Current Opinion in Genetics and Development, $\mathbf{1 5}$, 454-460.

Janssens, S. B., Knox, E. B., Huysmans, S., Smets, E. F. and Merckx, V. S. F. T. (2009). Rapid radiation of Impatiens (Balsaminaceae) during Pliocene and Pleistocene: Result of a global climate change. Molecular Phylogenetics and Evolution, 52, 806-824.

Kaplan, D. R. (1984). The concept of homology and its central role in the elucidation of plant systematic relationships. pp. 51-70 in Duncan, T. and Stuessy, T. F. (eds.), Cladistics. Perspectives on the Reconstruction of Evolutionary History. New York: Columbia University Press.

Kawakita, A. and Kato, M. (2009). Repeated independent evolution of obligate pollination mutualism in the Phyllantheae-Epicephala association. Proceedings of the Royal Society B, 276, 417-426.

Kelly, L. M. and Stevenson, D. W. (2005). Floral morphological character coding and the use of trees. XVII International Botanical Congress, Vienna. Abstract 12.3.1.

Klingenberg, C. P. (2009). Morphometric integration and modularity in configurations of landmarks: tools for evaluating a priori hypotheses. Evolution and Development, 11, 405-421.

Kramer, E. M. and Hodges, S. A. (2010). Aquilegia as a model system for the evolution and ecology of petals. Philosophical Transactions of the Royal Society B, 365, 477-490.

Kramer, E. M. and Irish, V. F. (1999). Evolution of genetic mechanisms controlling petal development. Nature, 399, 144-148.

Lamb, R. S. and Irish, V. F. (2003). Functional divergence within the APETALA3/PISTILLATA floral homeotic gene lineages. Proceedings of the National Academy of Sciences USA, 100, 6558-6563.

Leinfellner, W. (1950). Der Bauplan des synkarpen Gynoeceums. Österreichische Botanische Zeitschrift, 97, 403-436.

Leins, P. (1964). Die frühe Blütenentwicklung von Hypericum hookerianum Wight et Arn. und $H$. aegypticum L. Berichte der Deutschen Botanischen Gesellschaft, 77, 112-123. 
Lexer, C., Joseph, J., van Loo, M. et al. (2009). The use of digital image-based morphometrics to study the phenotypic mosaic in taxa with porous genomes. Taxon, 58, 349-364.

Litt, A. (2007). An evaluation of A-function: evidence from the APETALA1 and APETALA2 gene lineages. International Journal of Plant Sciences, 168, 73-91.

Litt, A. and Stevenson, D. W. (2003a). Floral development and morphology of Vochysiaceae. I. The structure of the gynoecium. American Journal of Botany, 90, 1533-1547.

Litt, A. and Stevenson, D. W. (2003b). Floral development and morphology of Vochysiaceae. II. The position of the single fertile stamen. American Journal of Botany, 90, 1548-1559.

Marazzi, B. and Endress, P. K. (2008). Patterns and development of floral asymmetry in Senna (Leguminosae, Cassiinae). American Journal of Botany, 95, 22-40.

Marazzi, B., Endress, P. K., Paganucci de Queiroz, L. and Conti, E. (2006). Phylogenetic relationships within Senna (Leguminosae, Cassiinae) based on three chloroplast DNA regions: Patterns in the evolution of floral symmetry and extrafloral nectaries. American Journal of Botany, 93, 288-303.

Matthews, M. L. and Endress, P. K. (2002). Comparative floral structure and systematics in Oxalidales (Oxalidaceae, Connaraceae, Cephalotaceae, Brunelliaceae, Cunoniaceae, Elaeocarpaceae, Tremandraceae). Botanical Journal of the Linnean Society, 140, 321-381.

Matthews, M. L. and Endress, P. K. (2004). Comparative floral structure and systematics in Cucurbitales (Corynocarpaceae, Coriariaceae,
Datiscaceae, Tetramelaceae, Begoniaceae, Cucurbitaceae, Anisophylleaceae). Botanical Journal of the Linnean Society, 145, 129-185.

Matthews, M. L. and Endress, P. K. (2005a). Comparative floral structure and systematics in Celastrales (Celastraceae, Parnassiaceae, Lepidobotryaceae).

Botanical Journal of the Linnean Society, 149, 129-194.

Matthews, M. L. and Endress, P. K. (2005b). Comparative floral structure and systematics in Crossosomatales (Crossosomataceae, Stachyuraceae, Staphyleaceae, Aphloiaceae, Geissolomataceae, Ixerbaceae, Strasburgeriaceae). Botanical Journal of the Linnean Society, 147, 1-46.

Matthews, M. L. and Endress, P. K. (2006). Floral structure and systematics in four orders of rosids, including a broad survey of floral mucilage cells. Plant Systematics and Evolution, 260, 199-221.

Matthews, M. L. and Endress, P. K. (2008). Comparative floral structure and systematics in Chrysobalanaceae s.l. (Chrysobalanaceae, Dichapetalaceae, Euphroniaceae, and Trigoniaceae; Malpighiales). Botanical Journal of the Linnean Society, 157, 249-309.

Matthews, M. L., Endress, P. K., Schönenberger, J. and Friis, E. M. (2001). A comparison of floral structures of Anisophylleaceae and Cunoniaceae and the problem of their systematic position. Annals of Botany, 88, 439-455.

McMahon, M. M. and Hufford, L. (2005). Evolution and development in the amorphoid clade (Amorpheae: Papilionoideae: Leguminosae): Petal loss and dedifferentiation. International Journal of Plant Sciences, 166, 383-396. 
Melzer, S., Lens, F., Geman, J. et al. (2008). Flowering-time genes modulate meristem determinacy and growth form in Arabidopsis thaliana. Nature Genetics, 40, 1489-1492.

Merino Sutter, D. and Endress, P. K. (2003). Structure of female flowers an cupules in Balanopaceae, an enigmatic rosid family. Annals of Botany, 92, 459-469.

Nandi, O. I., Chase, M. W. and Endress, P. K. (1998). A combined cladistic analysis of angiosperms using $r b c L$ and nonmolecular data sets. Annals of the Missouri Botanical Garden, 85, 137-212.

O'Hara, R. J. (1988). Homage to Clio, or, toward an historical philosophy for evolutionary biology. Systematic Zoology, 37, 142-155.

Okuyama, Y., Pellmyr, O. and Kato, M. (2008). Parallel floral adaptations to pollination by fungus gnats within the genus Mitella (Saxifragaceae). Molecular Phylogenetics and Evolution, 46, 560-575.

Patterson, T. B. and Givnish, T. J. (2002). Phylogeny, concerted convergence, and phylogenetic niche conservatism in the core Liliales: Insights from $r b c \mathrm{~L}$ and $n d h \mathrm{~F}$ sequence data. Evolution, 56, 233-252.

Perret, M., Chautems, A., Spichiger, R., Barraclough, T. G. and Savolainen, V. (2007). The geographical pattern of speciation and floral diversification in the Neotropics: The tribe Sinningieae (Gesneriaceae) as a case study. Evolution, 61, 1641-1660.

Prenner, G. (2004). Floral development in Polygala myrtifolia (Polygalaceae) and its similarities with Leguminosae. Plant Systematics and Evolution, 249, 67-76.

Prenner, G. and Klitgaard, B. B. (2008). Towards unlocking the deep nodes of Leguminosae: Floral development and morphology of the enigmatic Duparquetia orchidacea (Leguminosae, Caesalpinioideae). American Journal of Botany, 95, 1349-1365.

Rasmussen, D. A., Kramer, E. M. and Zimmer, E. A. (2009). One size fits all? Molecular evidence for a commonly inherited petal identity program in Ranunculales. American Journal of Botany, 96, 96-109.

Razafimandimbison, S. G., Rydin, C. and Bremer, B. (2008). Evolution and trends in the Psychotrieae alliance (Rubiaceae) - A rarely reported evolutionary change of many-seeded carpels from one-seeded carpels. Molecular Phylogenetics and Evolution, 48, 207-223.

Ree, R. H. (2005). Phylogeny and the evolution of floral diversity in Pedicularis (Orobanchaceae). International Journal of Plant Sciences, 166, 595-613.

Remane, A. (1956). Die Grundlagen des natürlichen Systems, der vergleichenden Anatomie und der Phylogenetik. Leipzig: Akademische Verlagsanstalt.

Remizowa, M. V., Sokoloff, D. and Rudall, P. J. (2006). Evolution of the monocot gynoecium: Evidence from comparative morphology and development in Tofieldia, Japonolirion, Petrosavia and Narthecium. Plant Systematics and Evolution, 258, 183-209.

Ren, Y., Chang, H.-L. and Endress, P. K. (2010). Floral development in Anemoneae (Ranunculaceae). Botanical Journal of the Linnean Society, 162, 77-100.

Renner, S. S. and Schaefer, H. (2010). The evolution and loss of oil-offering flowers: New insights from dated phylogenies for angiosperms and bees. Philosophical Transactions of the Royal Society B, 365, 423-435. 
Richards, J. H., Bruhl, J. J. and Wilson, K. L. (2006). Flower or spikelet? Understanding the morphology and development of reproductive structures in Exocarya (Cyperaceae, Mapanioideae, Chrysotricheae). American Journal of Botany, 93, 1241-1250.

Ronse De Craene, L. P. (2007). Are petals sterile stamens or bracts? The origin and evolution of petals in the core eudicots. Annals of Botany, 100, 621-630.

Ronse De Craene, L. P. (2008). Homology and evolution of petals in the core eudicots. Systematic Botany, 33, 301-325.

Rosin, F. M. and Kramer, E. M. (2009). Old dogs, new tricks: Regulatory evolution in conserved genetic modules leads to novel morphologies in plants. Developmental Biology, 332, 25-35.

Rozefelds, A. C. and Drinnan, A. N. (2002). Ontogeny of pistillate flowers and inflorescences in Nothofagus subgenus Lophozonia (Nothofagaceae). Plant Systematics and Evolution, 233, 105-126.

Rudall, P. J. (2002). Homologies of inferior ovaries and septal nectaries in monocotyledons. International Journal of Plant Sciences, 163, 261-276.

Rudall, P. J. (2010). All in a spin: Centrifugal organ formation and floral patterning. Current Opinion in Plant Biology, 13, 108-114.

Sajo, M. G., Rudall, P. J. and Prychid, C. J. (2004). Floral anatomy of Bromeliaceae, with particular reference to the evolution of epigyny and septal nectaries in commelinid monocots. Plant Systematics and Evolution, 247, 215-231.

Sattler, R. (1992). Process morphology: Structural dynamics in development and evolution. Canadian Journal of Botany, 70, 708-714.

Schönenberger, J. (1999). Floral structure, development, and diversity in Thunbergia (Acanthaceae). Botanical Journal of the Linnean Society, 130, 1-36.

Schönenberger, J. (2005). Rise from the ashes - reconstruction of charcoal fossil flowers. Trends in Plant Science, 10, 436-443.

Schönenberger, J. and Conti, E. (2003). Molecular phylogeny and floral evolution of Penaeaceae, Oliniaceae, Rhynchocalycaceae, and Alzateaceae (Myrtales). American Journal of Botany, 90, 292-309.

Schönenberger, J. and Endress, P. K. (1998). Structure and development of the flowers in Mendoncia, Pseudocalyx, and Thunbergia (Acanthaceae) and their systematic implications. International Journal of Plant Sciences, 159, 446-465.

Scotland, R. W., Olmstead, R. G. and Bennett, J. R. (2003). Phylogeny reconstruction: The role of morphology. Systematic Biology, 52, 539-548.

Sebola, R. J. and Balkwill, K. (2009). Numerical phenetic analysis of Olinia rochetiana sensu lato (Oliniaceae). Kew Bulletin, 64, 95-121.

Simon, H. A. (1962). The architecture of complexity. Proceedings of the American Philosophical Society, 106, 467-482.

Simpson, M. G. (1998). Reversal in ovary position from inferior to superior in the Haemodoraceae: Evidence from floral ontogeny. International Journal of Plant Sciences, 159, 466-479.

Smith, S. D. and Baum, D. A. (2006). Phylogenetics of the florally diverse Andean clade Iochrominae (Solanaceae). American Journal of Botany, 93, 1140-1153. 
Soltis, D. E., Soltis, P. S., Endress, P. K. and Chase, M. W. (2005). Phylogeny and Evolution of Angiosperms. Sunderland, MA: Sinauer.

Soltis, P. S., Brockington, S. F., Yo, M.-J. et al. (2009). Floral variation and floral genetics in basal angiosperms. American Journal of Botany, 96, 110-128.

Staedler, Y. M. and Endress, P. K. (2009). Diversity and lability of floral phyllotaxis in the pluricarpellate families of core Laurales (Gomortegaceae, Atherospermataceae, Siparunaceae, Monimiaceae). International Journal of Plant Sciences, 170, 522-550.

Stevens, P. F. (2000). On characters and character states: Do overlapping and non-overlapping variation, morphology and molecules all yield data of the same value? pp. 81-105 in Scotland, R. W. and Pennington, T. (eds.), Homology and Systematics. Coding Characters for Phylogenetic Analysis. London: Taylor and Francis.

Stevens, P. F. (2001 onwards). Angiosperm Phylogeny Website. Available at http:// www.mobot.org/MOBOT/research/ APweb/.

Sweeney, P. W. (2008). Phylogeny and floral diversity in the genus Garcinia (Clusiaceae) and relatives. International Journal of Plant Sciences, 169, 1288-1303.

Takhtajan, A. (1964). The taxa of the higher plants above the rank of order. Taxon, 13, 160-164.

Tepfer, S. S. (1953). Floral anatomy and ontogeny in Aquilegia formosa var. truncata and Ranunculus repens. University of California Publications in Botany, 25, 513-648.

Tripp, E. A. and Manos, P. S. (2008). Is floral specialization an evolutionary dead-end? Pollination system transitions in Ruellia (Acanthaceae). Evolution, 62, 1712-1737.
Troll, W. (1928). Zur Auffassung des parakarpen Gynaeceums und des coenocarpen Gynaeceums überhaupt. Planta, 6, 255-276.

Tsou, C.-H. and Mori, S. A. (2007). Floral organogenesis and floral evolution of the Lecythidoideae (Lecythidaceae). American Journal of Botany, 94, 716-736.

Tucker, S. C. (1959). Ontogeny of the inflorescence and the flower in Drimys winteri var. chilensis. University of California Publications in Botany, 30, 257-336.

Turrill, W. B. (1938). The expansion of taxonomy with special reference to Spermatophyta. Biological Review, 13, 342-373.

Vargas, A. O. and Wagner, G. P. (2009). Frame-shifts of digit identity in bird evolution and cyclopamine-treated wings. Evolution and Development, 11, 163-169.

Wagner, G. P. (1989). The biological homology concept. Annual Reviews in Ecology and Systematics, 20, 51-69.

Wagner, G. P. (2005). Concepts matter: characters as units of evolutionary change. XVII International Botanical Congress, Vienna. Abstracts, p. 215.

Wagner, G. P. (2007). The developmental genetics of homology. Nature Reviews Genetics, 8, 473-479.

Wagner, G. P. (2009). BIO. Evolution and Development, 11, 139-141.

Wanntorp, L. and Ronse De Craene, L. P. (2009). Perianth evolution in the sandalwood order Santalales. American Journal of Botany, 96, 1361-1371.

Warner, K. A., Rudall, P. J. and Frohlich, M. W. (2009). Environmental control of sepalness and petalness in perianth organs of waterlilies: A new mosaic theory for the evolutionary origin of a differentiated perianth. Journal of Experimental Botany, 60, 3559-3574. 
Wen, J., Plunckett, G. M., Mitchell, A. D. and Wagstaff, S. J. (2001). The evolution of Araliaceae: A phylogenetic analysis based on ITS sequences of nuclear ribosomal DNA. Systematic Botany, 26, 144-167.

Wilson, P., Wolfe, A. D., Armbruster, W. S. and Thomson, J. D. (2007). Constrained lability in floral evolution: Counting convergent origins of hummingbird pollination in Penstemon and Keckiella. New Phytologist, 176, 883-890.
Yoo, M.-J., Soltis, P. S. and Soltis, D. E. (2010). Expression of floral MADSbox genes in two divergent 'water lilies': Nymphaeales and Nelumbo. International Journal of Plant Sciences, 171, 121-146.

Zachgo, S., Perbal, M.-C., Saedler, H. and Schwarz-Sommer, Z. (2000). In situ analysis of RNA and protein expression in whole mounts facilitates detection of floral gene expression dynamics. Plant Journal, 23, 697-702. 